\title{
A study on the Development of Semurup Hot Spring Tourism Object at District of Air Hangat in Kerinci Regency
}

\author{
Shinta Anggia \\ Student of Geography Education Master Program, \\ Faculty of Social Sciences, Universitas Negeri Padang, INDONESIA \\ Email:shinta@gmail.com
}

\begin{abstract}
This study aimed to investigate the physical and nonphysical characteristics, management and development strategies of Semurup or Spring tourism and to formulate policy directions of Semurup Hot Spring Tourism object development. The researcher combined to types of studies, qualitative and quantitative study (mixed method research) and used SWOT analysis and AHP analysis to analyze the data. The result of this research showed that (1) its physical characteristics (location, acessibility, attraction, amenity/facility) had met the criteria of tourism mentioned in The Regulation of Ministry of Public Workss number 41/Prt/M/2007 and its nonphysical characteristics (social-culture-economic and Sapta Pesona/sapta charm) did not yet give a positive impact on the development of Semurup Hot Spring tourism object (2) Management system of Semurup hot spring tourism object was directly managed by Government Tourism Office. (3) the development strategies were analyzed by SWOT analysis and there were eleven strategies which can be used to develop Semurup Hot Spring trousim object (4) policy direction of the development of Semurup Hot Spring tourism object by using AHP analysis. The result of AHP analysis revealed that there were five policy direction of Semutup Hot Spring tourism, namely: (a) promoting the tourism object $(0.785)$, (b) the socialization about tourism awareness to improve local community' knowledge of the tourism object (0.786), (c) involving the local comunity in the tourism management (0.779), (d) improving and increasing the facilties and infrastructure of Semurup hot spring tourism object $(0.755)$, and (e) supporting local community's creative economy activities (0.718).
\end{abstract}

Keywords; Tourist Policy, Semurup Hot Spring tourism object.

\section{Introduction}

Indonesia is an archipelagic country that has a tremendous natural wealth that is very potential to be developed in the field of tourism. not only its natural wealth but Indonesia also has various cultures and arts in every region that make its regions to have their own characteristics and uniqueness which often published by other regions or countries. The characteristic or the uniqueness of a region can used as an attractive tourism. In RI law number 10 year 2009 related to tourism Article 1; Tourism is a multi-dimensional and multidisciplinary tourism-related activity that emerges as a manifestation of the needs of every person and country as well as the interaction between tourists and the local community, fellow travelers, governments, local governments and businessmen.

Kerinci is one of Regencies in Jambi Province which has tourism object and attraction such as natural tourism, cultural tourism, and artificial tourism. Various tourist objects and attractions existing in Kerinci Regency can be agood potential sources of regional income. However, the tourism in kerinci does not have optimal management, for example Semurup Hot Spring tourism object. What become the main attraction of this place is the presence of geyser. 
Semurup Hot Spring is located at Air Panas Baru village RT 01/RW 01, District of Air Hangat, erincy Regency. Semurup Hot Spring is $8 \mathrm{~km}$ from Sungai Penuh City and can be reached in aproximately 1.5 hours. The road is paved and has a width of 4 meters. Semurup Hot Spring is a attractive and unique tourism. The hot water coming out of the earth is the result of volcanic activity. Its location is in the active fault zone of Sumatera on the edge of graben. The hot water that comes to the surface forms a hot water pool which is always steaming. Its temperature is about $80^{\circ}-95^{\circ} \mathrm{C}$ and it has an area of $15 \mathrm{~m}^{2}$, a depth of 5 meter and there are siliceous sinter deposits around the lip of the pool. after 1995 and 2009 earthquakes, Semurup's Hot Spring level decreased significantly. The main hot spring that used to supply swimming pools around it, now can only supply water for bathrooms. The condition of the hot spring is affected by Sumatera's major fault activity that is periodically affected by tectonic earthquake. The earthquake occurs when the planet's plates move againts one another. This movement can create stress that cause the earth's exterior shell, the lithosphere, to shift or break. These activities will affect the pressure and the temperature of the hot spring (Disporabudpar 2015, Secondary Data). In the preliminary research, the researcher found that Semurup Hot Spring was managed by the government and there was no cooperation between government and local people although Semurup Hot Spring was located in the residential area. There were ten houses surrounded this tourism object. Moreover, many facilities and infrastructure were not in good condition and were not taken care of that resulted in the lack of tourists' enthusiasts to visit the hot spring.

\section{Method}

This research was a descriptive qualitative research that employed observation, interview, and documentation study as instruments to collect the data. Two types of data were collected, namely primary data and secondary data. The data was obtained from Government Agency in Kerinci Regency (BAPEEDA) and Government Tourism Office. Primary data was collected by conducting deep interview with the informants and by conducting an observation about the condition of Semurup Hot Spring. Secondary data was taken from monographic data and internet regarding regional information and published documents of related Agencies. The participants of this research were local people, public figure, visitors, Government Tourism Office and the tourism manager. Technique of data analysis used were SWOT analysis and AHP (analytical Hierarchy Process) analysis. SWOT analysis was used to analyze the data of Semurup Hot Spring Tourim Object development and AHP analysis was used to formulate the policy directions for the development of Semurup Hot Spring Tourism Object in District of Air Hangat, Kerincy Regency.

\section{Result and Discussion}

Kerinci was decided as one of regencies in Jambi in 2009 and expanded to two administrate areas, Kerinci and Sungai Penuh City. After the expansion, kerinci has a space of $332.842 \mathrm{~km}^{2}$ and 16 distiricts. Kerinci is called as a land from paradise by it people because of its beautiful morphological condition. Kerinci is surrounded by Barisan Hills and has 3805 meter amsl mountain in Sumatera which is the highest mountain in Sumatera. The existence of the mountain fetilize the land in the foot of the mountain that is used for agriculture. Moreover, its morphological condition also makes Kerinci to have temperature of $18-22^{\circ} \mathrm{C}$.

District of Kerinci is also well-known for its attractive tourism objects such as Kayu Aro tea gardens, Lake of Kerinci, Waterfalls, and hot springs. One of favrite hot spring tourism objects is Semurup Hot Spring which is located on Air Panas Semurup Village in west Air Hangat District . This tourism object was legalized in 1990 by Government Tourism Office of Kerinci and the local people. In order to attract more visitors, Semurup Hot Spring needs a proper development. The development can be done by considering some aspects such as physical and nonphysical aspects, the management, development strategies, and policy 
directions of the development of Semurup Hot Spring tourism object. Based on the resut of this study,it was found that Semurup Hot Spring did not have an optimal managements and adequate facilties and infrastructure to support tourism activities. This condition made any tourism potency in Semurup Hot Spring difficult to be developed. Concerning the effort in increasing the number of visitors to this place, the researcher used SWOT and AHP analysis. By using the data from interview and observation, the researcher formulated 'strength and weaknesses (internal factors) and opportunities and threats (external factors) which were used to determine the SWOT scoring. The details of internal and external factors are displayed in the following table:

Table 1. SWOT scoring of Semurup hot spring tourism object

\begin{tabular}{|c|c|}
\hline \multicolumn{2}{|c|}{ Internal Factor } \\
\hline Strenghts $(S)$ & Weaknesses $(W)$ \\
\hline $\begin{array}{l}\text { The strong points of Semurup Hot Spring are: } \\
\text { a. The hot spring, Cullinary, and health. } \\
\text { b. A Good and smooth accessibility. the road is } \\
\text { paved and has a width of } 4 \text { meters. } \\
\text { c. The existence of hot water baths that can be } \\
\text { used as a treatment of skin diseases and } \\
\text { rheumatism. } \\
\text { d. Open-minded society. }\end{array}$ & $\begin{array}{l}\text { Weaknesses of Semurup Hot Spring Tourism } \\
\text { Object: } \\
\text { 1. A less clean environmet. } \\
\text { 2. Many damaged and unused facilities and } \\
\text { infrastructure such as swimmingpools, } \\
\text { toliet, inn, stage and others. } \\
\text { 3. It did not ivolve the local people in its } \\
\text { development. } \\
\text { 4. The community is not conscious of tourism } \\
\text { 5. Lack of training to improve the economy of } \\
\text { local communities. }\end{array}$ \\
\hline \multicolumn{2}{|c|}{ External Factor } \\
\hline Opportunity (O) & Threat (T) \\
\hline $\begin{array}{l}\text { Opportunities in developing tourism object of } \\
\text { Semurup Hot Spring: } \\
\text { a. Economic improvement } \\
\text { b. Employment } \\
\text { c. Additional local revenue } \\
\text { d. Semurup Hot Spring can be developed as a } \\
\text { potential health tourism. }\end{array}$ & $\begin{array}{l}\text { Threats in developing tourism object of Semurop } \\
\text { Hot Spring: } \\
\text { a. Prone to environmental damage } \\
\text { b. Competing with other tourism objects. } \\
\text { c. The occurence of crime } \\
\text { d. the absence of local cuisine }\end{array}$ \\
\hline
\end{tabular}

Based on these internal and external factor of Tourism Object of Semurup Hot Spring, the strategies were determined. There were 4 types of strategy:

1. S-O strategy, a strategy that make use of the strengths to use the opportunities. This strategy is based on the company's way of thinking; "using all the strength you have to grab and use the opportunities as mush as possible".

2. W-O strategy, a strategy that minimize the weaknesses and make use of the opportunities.

3. S-T strategy, a strategy that use the strength to overcome the threats.

4. W-T strategy, a strategy that minimize the weaknesses and avoid the threats.

That strategies would be used alternatives of the development of Semurup Hot Spring Tourism Object.The explanation of formulated strategies is mentioned as follow: 
Table 2. SWOT strategies of Semurup hot spring tourism object

\begin{tabular}{|c|c|c|}
\hline \multirow[t]{2}{*}{ Internal Factor } & Strenghts (S) & Weaknesses (W) \\
\hline & $\begin{array}{l}\text { a. Tourism, Cullinary and } \\
\text { health attractions. } \\
\text { b. a good and smooth } \\
\text { accessibility, paved and } 4 \\
\text { meters wide road. } \\
\text { c. The existence of hot water } \\
\text { baths that can be used as a } \\
\text { treatment of skin diseases } \\
\text { and rheumatism. } \\
\text { d. Open-minded society }\end{array}$ & $\begin{array}{l}\text { a. A less clean environmet. } \\
\text { b. Many damaged and unused } \\
\text { facilities and infrastructure such } \\
\text { as swimmingpools, toliet, inn, } \\
\text { stage and others. } \\
\text { c. It did not ivolve the local people } \\
\text { in its development. } \\
\text { d. The community is not conscious } \\
\text { of tourism } \\
\text { e. Lack of training to improve the } \\
\text { economy of local communities. }\end{array}$ \\
\hline \multicolumn{3}{|l|}{ External Factor } \\
\hline Opportunities (O) & Strategy (SO) & Strategy (WO) \\
\hline $\begin{array}{ll}\text { a. } & \text { Economic } \\
\text { improvement } \\
\text { b. Employment } \\
\text { c. Additional local } \\
\text { revenue } \\
\text { d. Semurup Hot } \\
\text { Spring can be } \\
\text { developed as a } \\
\text { potential health } \\
\text { tourism. }\end{array}$ & $\begin{array}{l}\text { a. government and local people } \\
\text { cooperate in developing } \\
\text { Semurup Hot Spring as a } \\
\text { health tourism object. } \\
\text { b. The government and the } \\
\text { community jointly promote } \\
\text { Semurup Hot Water } \\
\text { attractions }\end{array}$ & $\begin{array}{l}\text { a. Reconstructing old facilities and } \\
\text { infrastructure and add the new ones } \\
\text { b. Giving an understanding to the local } \\
\text { people about the importance of } \\
\text { maintaining and protecting the area of } \\
\text { Semurup Hot Springs. } \\
\text { c. Focusing on repairing hot water bath } \\
\text { facilities so that visitors interested to } \\
\text { come and can feel its health benefit } \\
\text { d. Involving local people in managing } \\
\text { tourism object of Semurup Hot Spring. }\end{array}$ \\
\hline Treaths (T) & Strategy (ST) & Strategy $(W T)$ \\
\hline $\begin{array}{l}\text { a. } \begin{array}{l}\text { Prone to } \\
\text { environmental } \\
\text { damage }\end{array} \\
\text { b. } \begin{array}{l}\text { Competing with } \\
\text { other tourism } \\
\text { objects. }\end{array} \\
\text { c. The occurence of } \\
\text { crime } \\
\text { d. the absence of } \\
\text { local cuisine }\end{array}$ & $\begin{array}{l}\text { a. Developing eco-friendly } \\
\text { tourism object. } \\
\text { b. Supporting local economic } \\
\text { activities, for example, by } \\
\text { providing venture capital and } \\
\text { giving a training to develop } \\
\text { special cullinary of Semurup } \\
\text { Hot Spring. }\end{array}$ & $\begin{array}{l}\text { a. Improving the cooperation relationship } \\
\text { between the community and the } \\
\text { government in the development of } \\
\text { tourism object. } \\
\text { b. building a guard house and } \\
\text { implementing rotating guard system so } \\
\text { the men can protect the area from } \\
\text { crimes. } \\
\text { c. maintaining cleanliness and facilities } \\
\text { in the tourism environment. }\end{array}$ \\
\hline
\end{tabular}

The strategies that were suggested through SWOT analysis in developing tourism object of Semurup Hot Spring are:

1. government and local people cooperate in developing Semurup Hot Spring as a health tourism object

2. The government and the community jointly promote Semurup Hot Spring attractions

3. Reconstructing old facilities and infrastructure and add the new ones.

4. Giving an understanding to the local people about the importance of maintaining and protecting the area of Semurup Hot Springs.

5. Focusing on repairing hot water bath facilities so that visitors interested to come and can feel its health benefit

6. Involving local people in managing tourism object of Semurup Hot Spring.

7. Developing eco-friendly tourism object

8. Supporting local economic activities, for example, by providing venture capital and giving a training to develop special cullinary of Semurup Hot Spring. 
9. Improving the cooperation relationship between the community and the government in the development of tourism object.

10. building a guard house and implementing rotating guard system so the men can protect the area from crimes.

11. Socializing the tourism to local people so they understand and are aware of tourism.

Policy hierarchy cab be seen in Figure. It displays three aspects of development policy of Semurup Hot Spring tourism, namely; (1) physical and nonphysical condition of Semurup Hot Spring tourism, (2) management of Semurup Hot Water tourism, and (3) Development strategies of Semurup Hot Spring tourism. The three policy aspects develop into 11 policy alternatives. They are 1) Government Tourism office and local people cooperate in developing Semurup Hot Spring as a health tourism object, 2) Promoting Semurup Hot Spring tourism, 3) Reconstructing old facilities and infrastructure of the tourism and add the new ones, 4) Giving an understanding to the local people about the importance of maintaining and protecting the area of Semurup Hot Springs, 5) Focusing on repairing hot water bath facilities so that visitors interested to come and can feel its health benefit, 6) Involving local people in managing tourism object of Semurup Hot Spring. 7) Developing eco-friendly tourism object, 8) Supporting local economic activities, for example, by providing venture capital and giving a training to develop special cullinary of Semurup Hot Spring, 9) Improving the cooperation relationship between the community and the government in the development of tourism object, 10) Building a guard house and implementing rotating guard system so the men can protect the area from crimes, and 11) Socializing the tourism to local people so they understand and are aware of tourism.

The relative comparative values were analyzed by Expert Choise program version 3.0 to determine the rank of all alternatives. the consistency ratio value of policy directions is 0.069 or $<0.1$. This means the policy heirarchy arranged in this research was considered to be consistent and applicable. Figure 3 shows the detail of the consistency ratio of policy direction in this research. Based on the analysis above and discussion with related agencies or parties in this research, there were five priorities of alterative policy, namely; 1) Promoting Semurup Hot Spring tourism (0.795). 2) Socializing tourism awareness to local people to improve their knowledge about tourism (0.786). 3) Involving local communities in managing Semurup Hot Spring tourism (0.779). 4) Reconstructing old facilities and infrastructure of the tourism and add the new ones (0.755). 5) Supporting community's creative economic activities (0.718). Each policy will be implemented by:

1. Promoting Semurup Hot Spring tourism

a. Making leaflet, booklet, brochure, tourist guide book, tourist map and others.

b. Doing a virtual advertisement in website so public will easily access the homepage anytime and anywhere. advertising shoulg be done by authorized institution whether it is the government of credible and responsible private parties.

c. Advertising policy through tour packages can be done by combining Semurup Hot Spring tourism with other tourism objects in Kerinci such as Lake of Kerinci, Aroma Pecco, Danau 7, Danau Kaco, Panorama Puncak (Landscape or peak viewing).

d. Planning a monthly event, for example Kerinci performing arts, in Semurup Hot Spring tourism object.

2. Socializing tourism awareness to local people to improve their knowledge about tourism

a. Forming a tourism caring community.

b. Conducting a weekly discussion with the local people about public complaints againts tourists.

c. Trusting the local people to manage and maintain the rourism object. 
d. Involving local people in important event in order to improve tourism object development.

3. Involving local comunity in managing Semurup Hot Spring tourism object

a. Conducting meeting to discuss about the development of the tourism object

b. Creating a synergistic relationship between Governement Tourism Agency, Managers, and local community.

c. Actively doing tourism promotion in certain events.

d. Actively conducting meeting to buil a good cooperation.

e. Planning on developing the tourism object woth the local people.

f. building a guard house and implementing rotating guard system so the men can protect the area from crimes

4. Reconstructing old facilities and infrastructure of the tourism and add the new ones

a. Recording badly, moderately, and lightly damaged tourism facility.

b. Making a planning framework for repairing facilities and infrastructure of the tourism object.

c. Reconstructing existing facilities and infrastructure of the tourism object such as swimming pools and VIP bathrooms.

d. Adding more facilities and infrastructure that can support tourism activities in Semurup Hot Spring for example providing pebble therapy as one of health tourism activity, adding aroma therapy in VIP bathrooms, and creating a garden for herbal medicinal plants.

e. Building main tourism facilities such as (1) accomodation, resturant, shops, bank, and others (2) building an area for outbound activities, parking lot and (3) improving the accessibility through adding the numbers of vehicle (4) building a terminal

5. Supporting community's creative economic activities

a. Providing shops and diving rentals around tourism area.

b. providing venture capital and giving a training to develop special cullinary of Semurup Hot Spring.

c. Empower local people to make souvenirs.

d. Training the community in making handicrafts as Semurup Hot Spring special souvenirs.

e. Providing capital assistance to the community.

f. Establishing saving and loan cooperative which provides the community with venture capital.

g. Helping marketing the products made by local community to wider society.

h. Advertising the souvenirs to increase the sale of products.

\section{Conclusion}

Based on the analysis and discussion above, it can be concluded that Semurup Hot Spring tourism object has bad management and is lack of facilities and infrastructure. These factors become the reason why this tourism object does not attract many visitors. To solve the problem in developing Semurup Hot Spring tourism object, an analysis was done to formulate alternative development policy of Semurup Hot Spring by considering its physical and nonphysical characteristics, management, development strategies, ann development policy. The result of AHP analysis suggested five policy priorities to be implemented for the sake of Semurup Hot Spring development. They were; (1) Promoting Semurup Hot Spring tourism (0.795), (2) Socializing tourism awareness to local people to improve their knowledge about tourism (0.786), (3) Involving local communities in managing Semurup Hot Spring tourism (0.779), (4) Reconstructing old 
facilities and infrastructure of the tourism and add the new ones (0.755), and (5) Supporting community's creative economic activities $(0.718)$.

\section{Reference}

Agustin. Sentosa, Sriulfa. (2012). "Faktor-Faktor Yang Mempengaruhi Permintaan Wisatawan Domestik Terhadap Objek Wisata Bahari Pulau Cingkuak Kabupaten Pesisir Selatan”. Jurnal Kajian Ekonomi, Vol III, No. 5, Hal : 5.

Albone, Abdul Azis. Nawi, Marnis. Khairani. (2009). Panduan Penyusunan Proposal Penelitian dengan Mudah. Padang:Yayasan Jihadul Khair Center.

Anom, I. Putu. (2010). “Analisis Pariwisata”. Jurnal Fakultas Pariwisata Universitas Udayana. Vol. 10. No.1. Hlm. 4-5.

Arjana, Gusti, Bagus. (2016). Geografi Pariwisata dan Ekonomi Kreatif. Jakarta; PT Raja Grafindo Persada.

Badan Pusat Statistik Kabupaten Kerinci. (2015). Kerinci Dalam Angka 2015.

Bakkaruddin. (2009). Perkembangan dan Permasalahan Kepariwisataan. Padang; UNP Press.

Barus, Ternala Alexander. (2012). Pengantar Limnologi. Jurusan Biologi FMIPA USU. Medan

Bintarto. (1997). Analisa Wilayah. Bandung : Alfabeta.

Budhiyanti, Dwi. Dkk. (2010). “Konsep Ecotourism Pada Kawasan Wisata Nepa Sampang Madura”. Jurusan Teknil Planologi Program Studi Perencanaan Wilayah dan Kota Fakultas Teknik Sipil dan Perencanaan Institut Teknologi Malang. Jurnal Tata Kota dan Daerah. Volume 2, Nomor 1 Juli 2010.

Daldjoeni. (1982). Unsur Fisik dan Nonfisik Geografi. Jakarta : Gramedia

Damanik, Janianton, dan Weber, Helmut. (2006). Perencanaan Ekowisata dari Teori ke Aplikasi. Yogyakarta : Andi.

Damayanti, Maya. (2015). "Strategi Kota Pekalongan dalam Pengembangan Wisata Kreatif Berbasis Industri Batik". Jurusan Perencanaan Wilayah dan Kota, Fakultas Teknik, Universitas Diponegoro, Semarang. Jurnal Pengembangan Kota. Vol. 3. No. 2.

Gee, Chuk Y. (ed). (2000). Internasinal tourism A Global Perspective. Hawai : WTO Education Network.

Gering (2003). Manajemen Sumber Daya Manusia. Jakarta; Bumi Aksara.

Hermon, Dedi. (2009). Dinamika Permukiman dan Arahan Kebijakan Pengembangan Permukiman Pada Kawasan Rawan Longsor di Kota Padang Sumatera Barat. Tesis Pascasarjana; Bogor.

Ilyas, Muhammad. (2009). "Strategi Pengembangan Pariwisata Kepulauan Togean di Kabupaten Tojo Una-Una”. Tesis. Makasar; Program Studi Perencanaan Pengembangan Wilayah. Program Pasca Sarjana Universitas Hasanuddin.

Karay, C. Jonathan. (2012). "Memberdayakan Ekonomi Kerakyatan Sektor Pariwisata di Papua”. Jurnal Ekonomi dan Bisnis, vol. 2 No. 2, Hal. 1-2.

Karyono, Hari. (1997). Kepariwisataan. Jakarta; Gramedia.

Kurnianto, Imam Rudy. (2015). "Pengembangan Ekowisata (Ecotourism) di Kawasan Waduk Cacaban Kabupaten Tegal". Thesis Pada Program Studi Ilmu Lingkungan. Program Studi Magister Ilmu Lingkungan Program Pasca Sarjana Universitas Diponegoro.

Lestari, Sylva. (2015). “Analisis Pengembangan Obyek Wisata Alam di Resort Balik Bukit Taman Nasional Bukit Barisan Selatan”. Jurusan Kehutanan Fakultas Pertanian Universitas Lampung. Jurnal. Vol. 3 No. 1, hal. 4.

Muta'ali, Lutfi. (2012). Daya Dukung Lingkungan Untuk Perencanaan Pengembangan Wilayah. Universitas Gajah Mada.

Nafila, Oktaniza. (2013). "Peran Komunitas Kreatif dalam Pengembangan Pariwisata Budaya di Situs Megalitikum Gunung Padang”. Kementrian Pariwisata dan Ekonomi Kreatif Republik Indonesia. Jurnal Perencanaan Wilayah dan Kota, Vol. 24 No. 1, April 2013, hlm. 3.

Nandi. (2008). "Pariwisata dan Pengembangan Sumber Daya Manusia". Jurusan Pendidikan Geografi, jurnal "GEA" Jurusan Pendidikan Geografi, April 2008, Vol. 8, No.1 (hlm. 2).

Nasibu, Z. Iskandar. (2009). "Penerapan Metode AHP Sistem Pendukung Keputusan Penempatan Karyawan Menggunakan Aplikasi Expert Choise”. Jurnal Pelangi Ilmu. Vol 2 No 5: Hlm 180-193.

Nazir, Moh. (2005). Metode Penelitian. Bogor selatan; Ghalia Indonesia. 
Nuranisa. (2015). Strategi Pengembangan Objek Wisata Jembatan AKA di Kecamatan Bayang Utara Kabupaten Pesisir Selatan. Tesis tidak diterbitkan. Padang: Pascasarjana Universitas Negeri Padang.

Pitana, I Gde. (2009). Pengantar Ilmu Pariwisata. Yogyakarta; Andi.

Pitana, I Gde. (2010). Pengantar Ilmu Pariwisata. Yogyakarta; Andi.

Prasiasa, Putu Oka. (2011). Wacana Kontemporer Pariwisata. Jakarta; Salemba Humanika.

Primadany, Sefira Ryalita. Riyanto. Mardiyono. (2013). "Analisis Strategi Pengembangan Pariwisata Daerah" (Studi pada Dinas Kebudayaan dan Pariwisata Daerah Kabupaten Nganjuk). Jurusan Administrasi Publik, Fakultas Ilmu Administrasi, Universitas Brawijaya, Malang. Jurnal Administrasi Publik (JAP), Vol. 1, No. 4, Hal.3

Probowati, Ayu Niken. (2015). "Identifikasi Faktor Penentu Pengembangan Objek Wisata di Kabupaten Demak". Jurusan Ilmu Ekonomi dan Studi Pembangunan, Fakultas Ekonomi, Universitas Jember (UNEJ). Artikel Ilmiah Mahasiswa 2015.

Purnomo, Cahya. (2009). "Strategi Pemasaran Produk Wisata Minat Khusus Goa Cerme Imogiri Bantul". Akademi Maritim Yogyakarta. Jurnal Kharisma. Vol. 3(2). Hal.3.

Putri, T dan Andriani, M. (2011). "Penerapan Sadar Wisata dan Penguatan Citra Wisata Melalui Penanaman Tanaman Upakara di Kerambitan Kabupaten Tabanan”. Jurnal Udayana Mengabdi, 10 (02) : 90-94.

Rangkuti, Freddy. (2014). Analisis Swot. Jakarta; Gramedia Pustaka Utama.

Riduwan. (2012). Skala Pengukuran Variabel-Variabel Penelitian. Jawa Barat; Alfabeta.

Romani, Siam. (2006). Penilaian Potensi Objek dan Daya Tarik Wisata Alam serta Alternatif Perencanaannya di Taman Nasional Bukit Duabelas Provinsi Jambi. Konservasi Sumberdaya Hutan dan Ekowisata. Fakultas Kehutanan. Institut Pertanian Bogor.

Rusli Ibrahim. (2001). Landasan Psikologi Pendidikan Jasmani di Sekolah Dasar. Deperteman Pendidikan Nasional. Dirjen Pendidikan Dasar dan Menengah.

Santi, Nila Ulva. (2010). "Perencanaan Strategis Pengembangan Objek Wisata Candi Cetho Oleh Dinas Pariwisata dan Kebudayaan Kabupaten Karanganyar". Jurnal Universitas Sebelas Maret, Vol, 10 (01); 23.

Sayangbatti, Dilla Pratiyudha, dan m. Baiquni. (2013). "Motivasi dan Persepsi Wisatawan tentang Daya Tarik Destinasi terhadap Minat Kunjungan Kembali di Kota Wisata Batu". Jurnal Nasional Pariwisata. Vol.5, No. 2, Hal; 5.

Sasmito, Adi. (2016). “Kawasan Wisata Pantai Caruban di Rembang”. Dengan pendekatan konsep Arsitektur Waterfront Frank Lloyd Wright. Jurnal Universitas Pandanaran. Vol. 3. No. 2. Hal; 3-2.

Simanjuntak, Susi Watina, dkk. (2015). Strategi Pengembangan Pariwisata Mangrove di Pulau Kemujan Karimunjawa. Program Studi Manajemen Sumberdaya Perairan, Jurusan Perikanan Fakultas Perikanan dan Ilmu Kelautan, Universitas Diponegoro. Jurnal. Volume 4, Nomor 1, Halaman; 25-34.

Siswantoro, Hariadi. (2012). "Kajian Daya Dukung Lingkungan Wisata Alam Taman Wisata Alam Grojogan Sewu Kabupaten Karanganyar". Thesis tidak diterbitkan. Semarang: Program Pascasarjana Universitas Diponegoro Semarang.

Soebagyo. (2012). "Strategi Pengembangan Objek Wisata Indonesia". Fakultas Ekonomi Universitas Pancasila. Jurnal liquidity. Vol. 1, No. 2. Hal; 153-154.

Sugiyono. (2012). Memahami Penelitian Kualitatif. Bandung; Alfabeta.

Suwantoro, Gamal. (2004). Dasar Pariwisata. Yogyakarta; Andi.

Umardiono, Andy. (2011). "Pengembangan Obyek Wisata Taman Nasional Laut Kepulauan Karimun Jawa". Program Studi D3 Kepariwisataan/Bina Wisata. Jurnal Volume 24, Nomor 3 Hal; 2.

Undang-Undang Republik Indonesia Nomor 10 Tahun 2009 Tentang Kepariwisataan.

Wadiyanta. (2006). Metode Penelitian Pariwisata. Yogyakarta; Andi.

Yasmen Chaniago. (2010). Konsep Sadar Wisata dan sapta pesona, URL; http://www.wisatakandi.com/. Diakses tanggal 10 maret 2016.

Yoeti, Oka. 1996. Pengantar Ilmu Pariwisata. Bandung; Angkasa.

Yunita, Mirna. (2014). Strategi Pengembangan Pariwisata Kabupaten Lahat Sumatera Selatan.Thesis tidak diterbitkan. Padang; Pascasarjana Universitas Negeri Padang.

Yusuf, A. Muri. (2007). Metodologi Penelitian. Padang; UNP Press. 